\title{
Development of a warning system for wheat blast caused by Pyricularia grisea.
}

\author{
Cinara Araújo de Andrade Cardoso, Erlei Melo Reis \& Eder Novaes Moreira
}

Faculdade de Agronomia e Medicina Veterinária da Universidade de Passo Fundo, Cx. Postal 631, Passo Fundo-RS, Brazil 99001-970, cinaraac@terra.com.br. Corresponding author: Erlei Melo Reis

Data de chegada: 10/07/2007. Aceito para publicação em: 07/07/2008

\begin{abstract}
Cardoso, C.A. de A., Reis, E.M. \& Moreira, E.N. Desenvolvimento de sistema de previsão de brusome causada por Pyricularia grisea. Summa Phytopathologica, v.34, n.3, p.216-221, 2008

Wheat (Triticum aestivum L.) blast caused by Pyricularia grisea is a new disease in Brazil and no resistant cultivars are available. The interactions between temperature and wetness durations have been used in many early warning systems. Hence, growth chamber experiments to assess the effect of different temperatures $(10,15$, $20,25,30$ and $\left.35^{\circ} \mathrm{C}\right)$ and the duration of spike-wetness $(0,5,10,15$, $20,25,30,35$ and 40 hours) on the intensity of blast in cultivar BR23 were carried out. Each temperature formed an experiment and the duration of wetness the treatments. The highest blast intensity was observed at $30^{\circ} \mathrm{C}$ and increased as the duration of the wetting period increased while the lowest occurred at $25^{\circ} \mathrm{C}$ and 10 hours of spike wetness. Regardless of the temperature, no

symptoms occurred when the wetting period was less than 10 hours but at $25^{\circ} \mathrm{C}$ and a $40 \mathrm{~h}$ wetting period blast intensity exceeded $85 \%$. These variations in blast intensity as a function of temperature are explained by a generalized beta model and as a function of the duration of spike wetness by the Gompertz model. Disease intensity was modeled as a function of both temperature and the durations of spike wetness and the resulting equation provided a precise description of the response of $P$ grisea to temperatures and the durations of spike wetness. This model was used to construct tables that can be used to predict the intensity of $P$. grisea wheat blast based on the temperatures and the durations of wheat spike wetness obtained in the field.
\end{abstract}

Additional keywords: Triticum aestivum, forecasting system

\section{RESUMO}

Cardoso, C.A. de A., Reis, E.M. \& Moreira, E.N. Development of a warning system for wheat blast caused by Pyricularia grisea. Summa Phytopathologica, v.34, n.3, p.216-221, 2008

Em experimentos conduzidos em câmaras de crescimento, com o cultivar suscetível de trigo BR 23 (Triticum aestivum L.) foram avaliadas as interações entre temperaturas e durações do período de molhamento contínuo das espigas sobre a intensidade da brusone (Pyricularia grisea). As temperaturas testadas foram de 10, 15, 20, 25,30 e $35^{\circ} \mathrm{C}$ e os períodos de duração do molhamento das espigas de $0,5,10,15,20,25,30,35$ e 40 horas. Cada temperatura constituiu um experimento e as horas de molhamento os tratamentos. A menor intensidade da doença foi observada a $25{ }^{\circ} \mathrm{C}$ com 10 horas de molhamento das espigas. Com molhamentos inferiores a 10 horas de duração não se observaram sintomas da doença em nenhuma das temperaturas. Intensidade de doença superior a $85 \%$ foi detectada a $25{ }^{\circ} \mathrm{C}$ com 40 horas de molhamento. As variações de intensidade da brusone do trigo pela temperatura foram explicadas pelo modelo Beta generalizado e o de duração de molhamento das espigas pelo modelo de Gompertz. A intensidade da doença foi modelada em função da temperatura e da duração do molhamento das espigas. A equação resultante fornece uma descrição precisa da resposta a intensidade da brusone aos efeitos combinados de temperatura e de duração do molhamento. O modelo foi usado para elaborar tabelas de períodos críticos que podem ser utilizadas na validação de um modelo de previsão da brusone em espigas de trigo segundo o modelo climático.

\section{Palavras-chave adicionais: Triticum aestivum, sistema de previsão.}

The worldwide epidemic occurrence of wheat (Triticum aestivum L.) blast caused by Pyricularia grisea (Saccardo), syn. P. oryzae (Cavara), teleomorph Magnaporthe grisea (Hebert) Barr, is a relatively recent phenomenon (5). In Brazil, P. grisea wheat blast was detected for the first time in the North of the state of Paraná in 1985 (5) and has subsequently been found in the main wheat-growing areas of Brazil, which includes the federal district of Brasília and the states of Goiás, Mato Grosso do Sul, São Paulo and Rio Grande do Sul as well as in the central-western Brazil where irrigated wheat is cultivated and where decreased wheat fields have been reported (17).
In rice (Oryza sativa $\mathrm{L}$ ), the conditions needed for infection with $P$. oryzae (the synonym for $P$. grisea) are $21-27^{\circ} \mathrm{C}$ and $10-14$ hours of spike wetness (12). However, the exact environmental conditions needed in wheat have not yet been clearly defined, although it is known that in crop pants temperature and spike wetness are the most important environmental factors affecting the relationship between plant-pathogens and their hosts.

Temperature generally accelerates biological processes and both plants and their pathogens require a minimum temperature for growth and development. This is why plant infections normally do not start 
during the colder seasons while the development of ongoing infections generally halt during such periods. However, as temperature increase pathogens become more agressive and when other environmental conditions become favorable can infect susceptible plants and cause disease (15). The effect of temperature on the development of a disease after infection depends on the type of the pathogen-host association. A disease normally develops most rapidly (i.e. the time required to complete the life-cycle of the pathogen is shortest) at the optimum temperature for the pathogen but generally above or below the optimum for the host. However, when temperatures are below or above the optimum for the pathogen, or are close to the optimum for the host, the development of the disease is slower (15).

The wetting period refers to the time that a plant organ is exposed to liquid water (20), the occurrence of liquid water on the surface of a plant constituting an important factor in the disease development. The importance of dew in relation to the wetting period can be important, and is especially accentuated when rainfall is infrequent and liquid water remains on the plant surface for a relatively short time.

According to Sutton (19), disease forecasting systems which use climatic models are based on the temporal and spatial presence of three decisive disease factors, a host, a plant pathogen and favorable atmospheric conditions which affect the infectious process. The response of fungal spores to wetting is automatic and irreversible and eventually leads to germination, because of which climatic models can predict infection (germination, germ tube growth, host penetration and the establishment of parasitism). Infection is successful when wetting (hw) occurs for sufficient time, and at a suitable temperature, to allow colonization of the host to be initiated, this interaction having been called the 'critical period' (CP) by Zadoks \& Schein (23). Therefore, if infection occurs during a critical period the surface of a spike may dry but the life cycle of the pathogen will continue because parasitism has already been established.

Kranz \& Hau (7) have pointed out that growth chamber studies carried out under controlled atmosphere conditions provide a solid base for understanding the effects of environmental factors on the development of plant epidemics. According to Rotem (21) data obtained in growth chamber studies provide an indication of what may happen in the field, although they cannot simulate with accuracy the development of the disease in nature because in the same way that a model is a simplified representation of reality a controlled atmosphere is a modified representation of the atmospheric conditions occurring during cultivation in the field.

The objective of our study was generate basic information to develop an early-warning system for wheat blast based on a climatic model, to which end we evaluated the relationship between temperature, spike wetting-period and disease intensity.

\section{MATERIALAND METHODS}

The research was carried out between 2004 and 2005 in the Plant pathology and Mycology Laboratory and in growth chambers of the Faculty of Agronomy and Veterinary Medicine, University of Passo Fundo, Rio Grande do Sul state, Brazil.

Seeds of the Brazilian wheat cultivar BR 23, susceptible to wheat blast caused by $P$. grisea were used throughout this work. The seeds were treated with the fungicide triadimenol (Bayer Crop Sciences, São Paulo, Brazil) at a rate equivalent to $40 \mathrm{~g}$ of active ingredient per $100 \mathrm{~kg}$ of seeds and the insecticide imidacloprid (Bayer Crop Sciences, São Paulo, Brazil) $\left(70 \%\right.$ WP) at a rate equivalent to 0.05 liters.ha $^{-1}$
(17) and sown in plastic pots containing $2.0 \mathrm{~kg}$ of substratum, 10 seeds being planted in each pot and the seedlings later thinned-out to five per pot. The pots were maintained in a greenhouse and fertilized once a week by adding $1.0 \mathrm{~mL}$ of a commercial fertilizer Niphokan [Fênix Agro - Pecus Industrial Ltda, Tietê - São Paulo) containing (g.L $\left.{ }^{-1}\right) 10.0 \% \mathrm{~N}, 8.0 \% \mathrm{P}_{2} \mathrm{O}_{5}, 8.0 \% \mathrm{~K}_{2} \mathrm{O}, 0.5 \% \mathrm{Mg}, 1.0 \% \mathrm{Ca}, 2.0 \%$ $\mathrm{S}, 1.0 \% \mathrm{Zn}, 0.5 \% \mathrm{~B}, 0.1 \% \mathrm{Fe}, 0.1 \% \mathrm{Mo}, 0.2 \% \mathrm{Cu}$ and $0.5 \% \mathrm{Mn}]$ to each liter of the water used for watering the plants. When the plants reached the booth stage (24) they were transferred to growth chambers and maintained at $25^{\circ} \mathrm{C}$ with a $12 \mathrm{~h}$ light/dark photoperiod.

The inoculum consisted of $P$. grisea obtained from naturally infected wheat spikes collected from wheat growing in Palotina country in the Brazilian state of Paraná. The inoculum was increased in Petri plates containing Potato dextrose agar [PDA, containing (g.L $\left.\mathrm{L}^{-1}\right)$ : peeled potato, 200; dextrose, 15; agar, 12] supplemented with + $200 \mathrm{mg} \mathrm{L}^{-1}$ streptomycin sulfate $(\mathrm{PDA}+\mathrm{S})$ prepared according to Fernandez (2). The plates were incubated at $25 \pm 2^{\circ} \mathrm{C}{ }^{\circ} \mathrm{C}$ for 30 days under a $12 \mathrm{~h}$ light/ dark photoperiod until abundant sporulation was obtained. After 25 days of incubation, conidia were removed from de culture using a camel brush and sterilized water containing 2 drops per liter of Tween 20 and determining the number of conidia per mL by counting in an appropriate counting chamber, the final conidial concentration was adjusted to $3 \times 10^{4}$ conidia $\mathrm{mL}^{-1}$ by serial dilution using the same diluent.

The wheat plants, maintained in the growth chambers as described above, were inoculated with the conidial suspension by manually spraying the wheat spikes during the anthesis stage. After inoculation, the plants were maintained in the growth chamber inside separate plastic humidity chambers for each treatment. Each humidity chamber contained its own sprayer to provide continuous wetting of the spikes during the specific times and temperatures of each treatment, the sprayer being electronically-controlled to provide one minute of water mist every 4 hours. At the end of each treatment period (see below), the plants were transferred to another growth chamber maintained at $25 \pm 2^{\circ} \mathrm{C}^{\circ} \mathrm{C}$ under a $12 \mathrm{~h}$ light/dark photoperiod and a relative humidity of $70 \%$, this low humidity being chosen to provide unfavorable conditions for fungal colonization and the development of blast.

\section{The effect of temperature and wetting-period}

The temperatures evaluated were $10,15,20,25,30$ and $35^{\circ} \mathrm{C}$ and the spike wetting-period was $0,5,10,15,20,25,30,35$ and 40 hours. Each temperature constituted an experiment and the wettingperiods the treatments.

Fifteen days after the plants were inoculated with P. grisea disease intensity was evaluated using a rating-class scale of 0 to 4 in which $0=$ healthy, absence of symptoms; $1=$ light, limited dark lesions at the base or along the rachis or light-colored elliptic lesions of the external parts of the glumes but without spikelet death; $2=$ light to moderate, death of one to seven isolated spikelets; $3=$ moderate, groups of dead spikelets covering $1 / 3$ to $2 / 3$ of the area of the spike; and $4=$ severe, death of the whole spike. The number of spiklets in each rating-class used to calculate the disease index DI\%, modified from Mckinney, (10) as follows: DI\% = (number of healthy spikelets $\mathrm{x} 0)+($ number of lightly-infected spikelets $\mathrm{x} 2)+($ number of light to moderately-infected spikelets $x 3)+($ number of moderately-infected spikelets x 5) + (number of severely-infected spikelets x 10) x 100 .

Each experiment was repeated twice and data pooled analysed.

\section{Statistical design}

A randomized experimental design with five replicates, with each experiment (temperature) containing nine treatments 
Table 1. The effect of temperatures and wetting-period on the intensity of wheat blast

\begin{tabular}{|c|c|c|c|c|c|}
\hline \multirow{3}{*}{ Duration of wetting-period (h) } & \multicolumn{5}{|c|}{ Temperature $\left({ }^{\circ} \mathrm{C}\right)$} \\
\hline & 15 & 20 & 25 & 30 & 35 \\
\hline & \multicolumn{5}{|c|}{ Disease Intensity $(\mathrm{Y} \% \pm \mathrm{SE})^{\mathrm{z}}$} \\
\hline 0 & 0 & 0 & 0 & 0 & 0 \\
\hline 5 & 0 & 0 & 0 & 0 & 0 \\
\hline 10 & 0 & 0 & $1.6 \pm 0.9$ & 0 & 0 \\
\hline 15 & 0 & $12.8 \pm 2.65$ & $14 \pm 3.29$ & $18.8 \pm 1.62$ & 0 \\
\hline 20 & 0 & $14.8 \pm 1.74$ & $9.2 \pm 3.26$ & $46.4 \pm 1.29$ & 0 \\
\hline 25 & $4 \pm 0.00$ & $42.4 \pm 5.91$ & $51.6 \pm 3.54$ & $74.0 \pm 3.69$ & 0 \\
\hline 30 & $4.8 \pm 1.2$ & $23.2 \pm 1.96$ & $71.2 \pm 2,65$ & $69.8 \pm 1.43$ & 0 \\
\hline 35 & $14 \pm 2.45$ & $54 \pm 4.09$ & $72.8 \pm 3.2$ & $79.2 \pm 0.8$ & 0 \\
\hline 40 & $20 \pm 0.04$ & $54.8 \pm 1.02$ & $86.4 \pm 3.76$ & $83.8 \pm 0.8$ & 0 \\
\hline
\end{tabular}

${ }^{2} \mathrm{SE}=$ standard error of the mean

corresponding to the different wetting-periods was used. Each experimental unit consisted of two pots each containing five plants, therefore each treatment contained 50 spikes.

\section{Statistical analysis of temperature and wetting effects}

The temperature data was adjusted using the non-linear procedure (NLIN) of the Statistical Analysis System (SAS) for Windows ${ }^{\circledR}$ program (version 8.0). Non-linear regression with the Beta function (3) was used to assess the effect of temperature on the development of disease where the intensity of the disease $(\mathrm{Y})=\mathrm{B} 1\left((\mathrm{X}-\mathrm{B} 2)^{\mathrm{B} 4}\right)((\mathrm{B} 3-$ $\mathrm{X})^{\mathrm{B} 5}$ ), where $\mathrm{B} 2$ represents the minimum temperature and $\mathrm{B} 3$ the maximum temperature, $\mathrm{X}$ represents the temperature and $\mathrm{B} 1, \mathrm{~B} 4$ and B5 are non-biological parameters of the model.

The wetting data was adjusted using the NLIN procedure in the SAS program. Non-linear regression was used to assess the effects of wetting using the Gompertz, Logistic and mono-molecular models described by Campbell \& Madden (1). The best model was chosen taking into account the largest adjusted determination coefficient $\left(\mathrm{R}^{* 2}\right)$, the mean square deviation, the smallest distribution of the residues and the shape of the curve observed verses predicted (6). Analysis showed that the Gompertz model best suited to explaining the effect of spike-wetting on blast intensity $(\mathrm{Y})$, where $\mathrm{Y}=\operatorname{EXP}\left(-\left(-\mathrm{LN}\left({ }_{y_{0}}\right)\right)\right.$ *EXP(-r*hw)), where yo is the initial inoculum, $r$ is the rate of progress for the Gompertz model and hw represents the duration of the spike-wetting period in hours.

The non-linear regression generated an equation which was used with the Microsoft Excel $6 \circledR$ spreadsheet to calculate the probability of different blast intensities using a scale of 0 to $100 \%$, the spreadsheet cells containing the desired blast intensity values ( 0 to $100 \%)$ and the temperature $\left(10^{\circ} \mathrm{C}\right.$ to $35^{\circ} \mathrm{C}$, in $1^{\circ} \mathrm{C}$ steps $)$ with the duration of the wetting-period (hw, in one-hour intervals) as an unknown.

\section{RESULTS AND DISCUSSION}

Many early warning systems are available in the literature are based on the relationship between temperature and wetness duration $(9,11,14,18,19,22)$.

The effects of temperature and wetting-period on the intensity of wheat blast is shown in Table 1. Irrespective of temperature, no symptoms of wheat blast were observed when the spike wettingperiod was less than $10 \mathrm{~h}$. The lowest blast intensity was observed at $25^{\circ} \mathrm{C}$ and the highest at $30^{\circ} \mathrm{C}$, both with a $10 \mathrm{~h}$ wetting-period. In

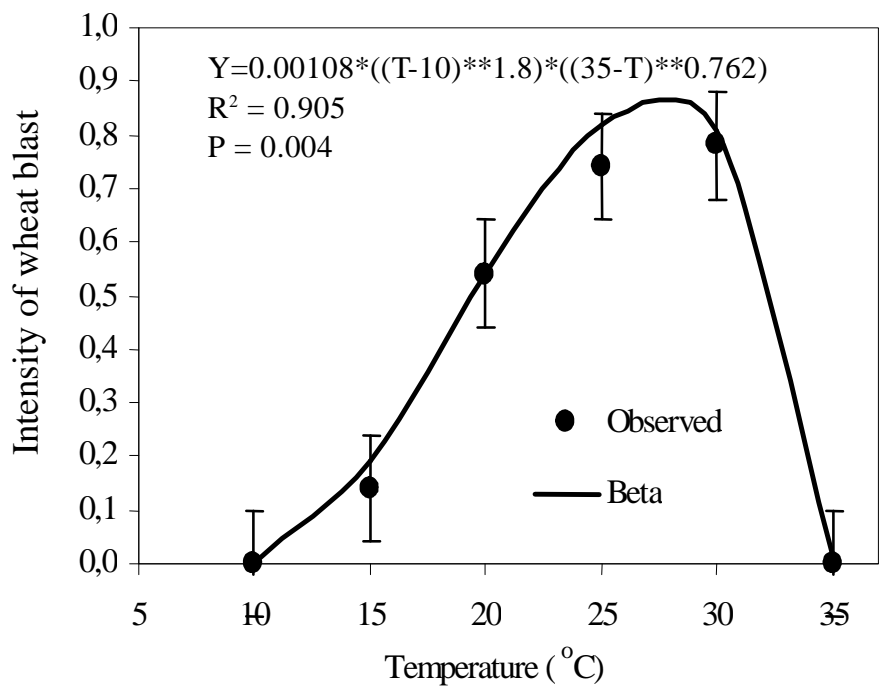

Figure 1. The effect of temperature $\left(\mathrm{T}^{\circ} \mathrm{C}\right)$ on the intensity $(\mathrm{y})$ of wheat blast. Each point represents the mean of five replicates. Bars show the standard error of the mean and the line represents the generalized beta model adjustment.

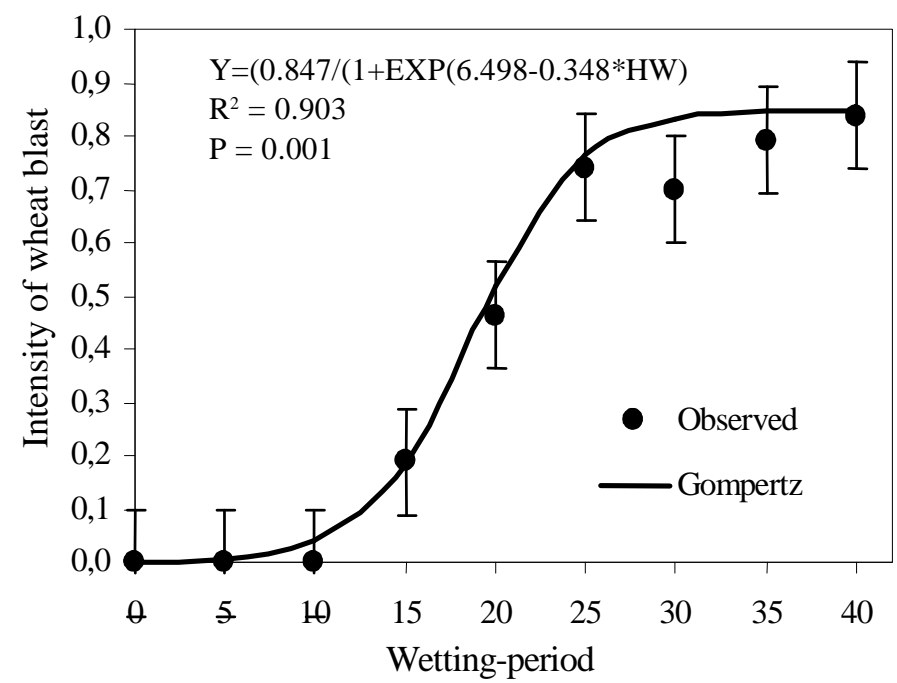

Figure 2. The effect of wetting-period (hw) on the intensity (y) of wheat blast. Each point represents the mean of five replicates. Bars show the standard error of the mean and the line represents the Gompertz model adjustment. 


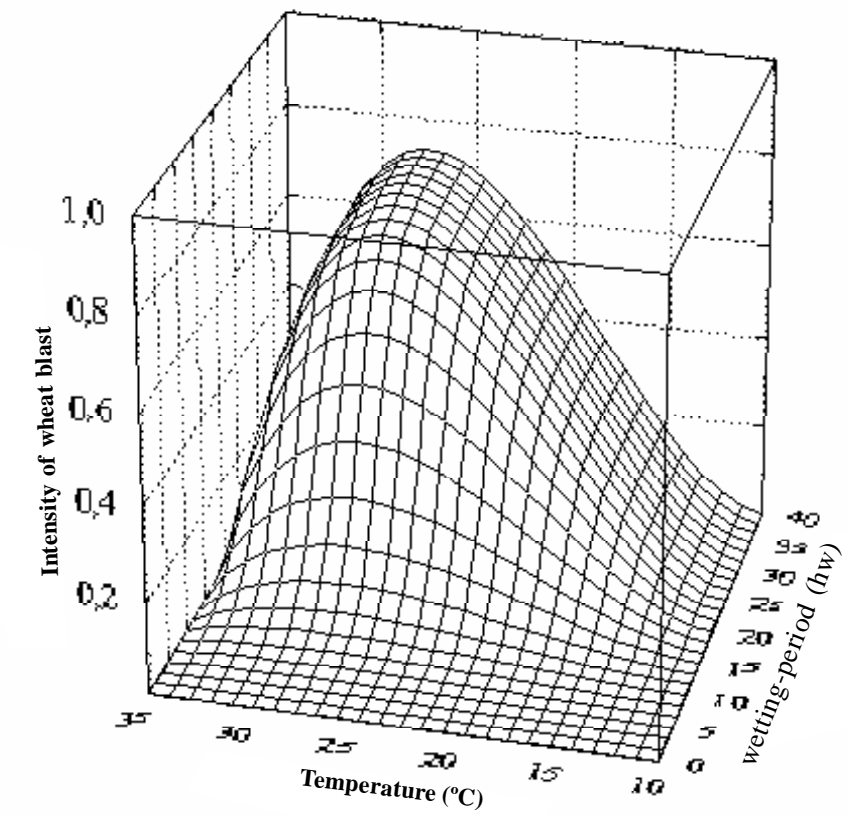

$\mathrm{Z}=0.00108 *((\mathrm{~T}-10.0) * * 1.8) *((35.0-\mathrm{T}) * * 0.762) *(0.847 /(1+\mathrm{EXP}(6.498-$ $0.348 * \mathrm{HW}))$

Figure 3. The effect of wetting-period (hw) and temperature (T) on the intensity $(\mathrm{Z})$ of wheat blast.

excess of $85 \%$ blast occurred at $25^{\circ} \mathrm{C}$ and a $40 \mathrm{~h}$ wetting-period.

\section{Temperature and blast intensity}

The effect of the temperature on the intensity of wheat blast is shown in Figure 1. The maximum blast intensity occurred between $25^{\circ} \mathrm{C}$ and $30^{\circ} \mathrm{C}$ and the lowest at $15^{\circ} \mathrm{C}$. Under the controlled conditions of our experiment we were unable to detected blast at $35^{\circ} \mathrm{C}$ because all the spikes turned white preventing evaluation, possibly because under the conditions of the experiment this temperature was too high for the wheat crop used. Rice panicles become infected with $P$. oryzae (the synonym of $P$. grisea) at $21^{\circ} \mathrm{C}$ to $27^{\circ} \mathrm{C}$ and with $10-14$ h of wetting (12), so our methodology might also be applicable to rice.

\section{Wetting-period and blast intensity}

The infection process was initiated only when the wettingperiod exceeded 10 hours (Figure 2). The blast intensity was highly influenced by the spike wetting-period, and when the wetting-period increased blast intensity increased. The wetting-period data fitted the Gompertz model, and combining the temperature and wetting-period equations as $(\mathrm{Z}=0.00108 *((\mathrm{~T}-10.0) * * 1.8) *((35.0-\mathrm{T}) * * 0.762) *(0.847 /$ $\left(1+\operatorname{EXP}\left(6.498-0.348^{*} \mathrm{HW}\right)\right)$ it was possible to create a threedimensional surface representing the temperature and wetting-period data (Figure 3).

The data relative to the interactions between the temperature and the duration of the spike wetting-period could be used to develop a basic forecasting systems based on the climatic model. Several similar climatic models have been published, including for apple scab (11), potato blight (22), Alternaria infection of tomato (9), tomato septoriosis (18), wheat scab (14) and soybean rust (13). In these cases the climatic models used the critical period concept (23) to predict infection and, in a similar fashion, our response-surface equation could be used to predict wheat blast.
A population of fungal spores does not germinate synchronously in response to temperature and moisture, so environmental factors such as temperature and the duration of the wetting period affect the ability of individual spores to successfully complete infection and hence the final intensity of the fungal diseases (19). Such effects are apparent in Figure 3.

In the Materials \& Methods we described how different disease intensities can be predicted using the temperature and wettingperiod data but disease intensity can also be obtained using different inoculum concentrations, temperatures and duration of leaf-wetting. The effect of the interaction between the leaf wetting-period and the average temperature during the wetting-period is the bases of disease forecasting systems which use the fundamental or inductive climatic model (23).

The effect of the interactions between temperature and the duration of the wetting-period on infection occurring under our controlled conditions can cause distortions when applied to the field. The factors which can cause such distortions are: temperature fluctuations, small interruptions in the duration of the wetting-period, different inoculum densities, variation in spore germination, host factors such as the age of susceptible tissues and organs, presence of nutrients or pesticides on the phylloplane and antagonistic biological activity of phylloplane microorganisms. This is why the absolute infection frequency is difficult to predict under field conditions (19).

One way that researchers have used to partly avoid such problems is to divide data on the response to infection into daily probability of infection (DPI) values. Krause and Massie (8) and Madden et al. (9) developed a disease forecasting system using a climatic model to develop a table of critical periods containing four arbitrary selected categories of infection efficiency, denominated daily severity values (DSV). Our proposal is to follow the same procedure of those models.

The procedure presented in this paper uses DPI values to produce a table of theoretical disease intensities at temperature intervals of $2,3,4$ and $5^{\circ} \mathrm{C}$, the disease intensity being represented as the percentage wheat spikes infected with wheat blast: $0=$ none; $1=0.1 \%$ to $20 \% ; 2=21 \%$ to $40 \% ; 3=41 \%$ to $60 \%$; and 4 $=61$ to $80 \%$ (Table 2 ).

We word 'daily' in the term 'daily probability of infection' was used to indicate that the wetting-period could, for example, be a daily and recurrent phenomenon due to dew, rain or fog, the future severity of the disease being a function of the infection efficiency of the spores that in turn is governed by the daily occurrence of the critical periods.

According to Madden et al. (9), the critical periods are different for each pathosystem, which is why DPI tables are different for each plant pathogen and host combination. Table 2 can serve as basis for the validation of the wheat blast warning system proposed in this study

A computer program has been developed that automatically combines mean temperature values and wetting-period values collected in the field by meteorological stations with the data from Tables 2 and calculates both daily probability of infection (DPI) values and the sum of the DPI (DDPI) values over a specified period. The different temperature intervals $\left(2,3,4\right.$ and $\left.5^{\circ} \mathrm{C}\right)$ are included in Table 2 with the aim of identifying the temperature and wetting period combination which best detects the initial symptoms of wheat blast under field conditions.

Validation trials are being conducted at two locations (Fundação ABC, Castro, Paraná, Brazil and Coodetec-cascavel, Cascavel, Paraná, Brazil) which suffer from frequent and severe wheat blast. 
Table 2. Interactions between temperature and the duration of the spike wetting-period (hw) needed to produce different daily probability of infection (DPI) values for the wheat blast fungus Pyricularia grisea. The values in each cell represent hours of wetting

\section{Daily probability of infection (DPI) category}

(Percentage spike infection intensity)

\begin{tabular}{|c|c|c|c|c|c|}
\hline Temperature $\left({ }^{\circ} \mathrm{C}\right)$ & $0($ No infection $)$ & $1(0.1$ to 20$)$ & $2(21$ to 40$)$ & $3(41$ to 60$)$ & $4(61$ to 80$)$ \\
\hline \multicolumn{6}{|l|}{$1^{\circ} \mathrm{C}$ intervals } \\
\hline 10 to 11 & $<5$ & 5 & - & - & - \\
\hline 12 to 13 & $<5$ & 5 & - & - & - \\
\hline 14 to 15 & $<5$ & 5 to 40 & - & - & - \\
\hline 16 to 17 & $<5$ & 5 to 21 & 22 to 40 & - & - \\
\hline 18 to 19 & $<5$ & 5 to 18 & 19 to 40 & - & - \\
\hline 20 to 21 & $<5$ & 5 to 17 & 18 to 22 & 23 to 40 & - \\
\hline 22 to 23 & $<5$ & 5 to 16 & 17 to 20 & 21 to 29 & 30 to 40 \\
\hline 24 to 25 & $<5$ & 5 to 16 & 17 to 19 & 20 to 24 & 25 to 40 \\
\hline 26 to 27 & $<5$ & 5 to 15 & 16 to 19 & 20 to 23 & 24 to 40 \\
\hline 28 to 29 & $<5$ & 5 to 16 & 17 to 19 & 20 to 23 & 24 to 40 \\
\hline 30 to 31 & $<5$ & 5 to 16 & 17 to 20 & 21 to 27 & 28 to 40 \\
\hline 32 to 33 & $<5$ & 5 to 18 & 19 to 25 & 26 to 40 & - \\
\hline 34 to 35 & $<5$ & - & - & - & - \\
\hline \multicolumn{6}{|l|}{$3^{\circ} \mathrm{C}$ intervals } \\
\hline 10 to 12 & $<5$ & 5 to 40 & - & - & - \\
\hline 13 to 15 & $<5$ & 5 to 40 & - & - & - \\
\hline 16 to 18 & $<5$ & 5 to 19 & 20 to 40 & - & - \\
\hline 19 to 21 & $<5$ & 5 to 17 & 18 to 22 & 23 to 40 & - \\
\hline 22 to 24 & $<5$ & 5 to 16 & 17 to 20 & 21 to 25 & 26 to 40 \\
\hline 25 to 27 & $<5$ & 5 to 16 & 17 to 19 & 20 to 23 & 24 to 40 \\
\hline 28 to 30 & $<5$ & 5 to 16 & 17 to 19 & 20 to 24 & 25 to 40 \\
\hline 31 to 33 & $<5$ & 5 to 18 & 19 to 25 & 26 to 40 & - \\
\hline 34 to 35 & $<5$ & - & - & - & - \\
\hline \multicolumn{6}{|l|}{$4^{\circ} \mathrm{C}$ intervals } \\
\hline 10 to 13 & $<5$ & 5 & - & - & - \\
\hline 14 to 17 & $<5$ & 5 to 21 & 22 to 40 & - & - \\
\hline 18 to 21 & $<5$ & 5 to 17 & 18 to 22 & 23 to 40 & - \\
\hline 22 to 25 & $<5$ & 5 to 16 & 17 to 19 & 20 to 24 & 25 to 40 \\
\hline 26 to 29 & $<5$ & 5 to 16 & 17 to 19 & 20 to 23 & 24 to 40 \\
\hline 30 to 34 & $<5$ & 5 to 21 & 22 to 40 & - & - \\
\hline 35 & $<5$ & - & - & - & - \\
\hline \multicolumn{6}{|l|}{$5^{\circ} \mathrm{C}$ intervals } \\
\hline 10 to 14 & $<5$ & 5 to 40 & - & - & - \\
\hline 15 to 19 & $<5$ & 5 to 19 & 20 to 40 & - & - \\
\hline 20 to 24 & $<5$ & 5 to 16 & 17 to 20 & 21 to 25 & 26 to 40 \\
\hline 25 to 29 & $<5$ & 5 to 16 & 17 to 19 & 20 to 23 & 24 to 40 \\
\hline 30 to 34 & $<5$ & 5 to 21 & 22 to 40 & - & - \\
\hline 35 & $<5$ & - & - & - & - \\
\hline
\end{tabular}

A dash (-) indicates that the incidence was not reached.

\section{REFERENCES}

1. Campbell, C.L.; Madden, L.V. Introduction of plant disease epidemiology. New York:John Wiley, 1990. 532p.

2. Fernandez, M.R. Manual para laboratório de fitopatologia. Passo Fundo:EMBRAPA/CNPT, 1993. 128. (EMBRAPA-CNPT. Documentos, 6).

3. Hau, B.; Kranz, J. Mathematics and statistics for analyses in epidemiology. In: Kranz, J. (Ed.) Epidemics of plant disease: mathematics analyses and modeling. Berlin:Springer-Verlag, 1990. p.

4. Igarashi, S. Uma análise da ocorrência de "brusone" do trigo no Paraná. In: Seminário sobre Melhoramento para a Resistência a Enfermidades, 1988, Passo Fundo. 19p.

5. Igarashi, S.; Utiamada, C.M.; Igarashi, L.C.; Kazuma, A.H.; Lopes, R.S. Pyricularia sp em trigo. Ocorrência de Pyricularia sp. no 
Estado do Paraná. In: Reunião nacional de pesquisa de trigo, 14., 1986, Londrina. Resumos. Londrina: IAPAR 1986. p.57.

6. Jesus Junior, W. C. de.; Pozza, A.E.; Vale, F.X.R do.; Aguirela, G.M. Análise temporal de epidemias. In: Vale, F.X.R do.; Cintra, J.J. de W.; Zambolim, L. Epidemiologia aplicada ao manejo de doenças de plantas. Belo Horizonte: Perffil Editora, 2004. p. $127-191$.

7. Kranz, J.; Hau, B. Systems analyses in epidemiology. Annual Review of Phytopathology, Palo Alto, v.18, p. 67-84, 1980.

8. Krause, R.A.; Massie, L.B. Predictive systems: modern approaches to disease control. Annual Review of Phytopathology, Palo Alto, v.13, p.31-47, 1975.

9. Madden, L.; Pennypacker, S.P.; Macnab, A.A. FAST, a forecast system for Alternaria solani on tomato. Phytopathology, St. Paul, v.68, n.9, p.1354-1358, 1978.

10. Mckinney, H.H. Influence of soil temperature and moisture on infection of wheat seedlings by Helminthosporium sativum. Journal of Agricultural Research. Washington,DC, v.26, n.26, p.195-217, 1923.

11. Mills, W.D.; La Plante, A.A. Disease and insect in the orchard. Ithaca, Cornell University, 1951. 100 p.

12. Ou, S. H. Fungus diseases - foliage diseases. In: Ou. S.H. Rice diseases. Surrey: Commonwealth Agricultural Bureaux. 1972. p. 97-184.

13. Reis, E.M.; Sartori. A.F.; Câmara. R.K. Modelo climático para a previsão da ferrugem da soja. Summa Phytopathologica, Botucatu, v.30, n.2, p.290-292. 2004.

14. Reis, E.M.; Blum, M.M.C. Modelo climático para a previsão da giberela em trigo. Summa Phytopathologica, Botucatu, v. 30, n. 4, p.497-500. 2004.
15. Reis, E.M.; Bresolin, A.C.R. Sistemas de previsão de doenças de plantas. In: Reis, E.M. Previsão de doenças de plantas. Passo Fundo: UPF, 2004. p. 155-287.

16. Reis, E.M.; Wordell, Filho J.A. Previsão de doenças de plantas. In: Reis, E.M. Previsão de doenças de plantas. Passo Fundo: UPF, 2004. p. 65-99.

17. Reunião da comissão centro sul-brasileira de pesquisa de trigo e triticale, 20. 2005, Londrina. Informações técnicas da comissão centro sul-brasileira de pesquisa de trigo e triticale para a safra de 2005. Londrina. Embrapa Soja, 2005. 234p.

18. Scaloppi, E.A.G. Desenvolvimento de um sistema de previsão da septoriose do tomateiro. 1999. 94f. Dissertação (Mestrado em Agronomia/Fitopatologia) - Universidade Estadual Paulista, Jaboticabal.

19. Sutton, J.C. Predictive value of weather variables in the epidemiology and management of foliar disease. Fitopatologia Brasileira, Brasília, v.12, n.4, p.305-312, 1988.

20. Sutton, J.C.; Gillespie, T.J.; Hildebrand, P. Monitoring weather factors in relation to plant disease. Plant Disease, St. Paul, v. 68, n.1, p.78-84, 1984.

21. Rotem, J. Techniques of controlled-condition experiments. In: Kranz, J.; Rotem, J. (Eds.). Experimental techniques in plant disease epidemiology. Berlin:Springer-Verlag, 1988. p. 19-31.

22. Wallin, J. R. Summary of recent progress in predicting late blight epidemics in United States and Canada. American Potato Journal, Oyona, v.39, p.306-312, 1962.

23. Zadoks, J.C.; Schein, R.D. Epidemiology and plant disease management. New York: Oxford University, 1979. 427p.

24. Zadoks, J.C.; Chang, T.T.; Konzak, C.F. A decimal code for the growth stages of cereals. Weed Research, v.14, n., p.415-421, 1974. 